- Relevant India Office Archives (microfilm);

- Complete collection of Brussels Information Centre on Eastern Arabia (1969-1979);

- Complete Middle East Economic Digest press cuttings and periodicals (from 1956). Microfiche copies of the former will be available for purchase;

- All possible reports and statistical information produced by ministries, monetary agencies, banks, oil companies, etc.;

- Journals and other publications of Arab Gulf universities and research centres;

- Copies of British and American Ph.D. theses relating to the Arab Gulf;

- Selected Arab Gulf newspapers and periodicals.

Publications: The Centre has an arrangement with Croom Helm for the publication under joint imprint of research works on the Arab Gulf (whether produced within the Centre or commissioned from outside). The Centre will also arrange translation and publication of Arabic language works on the Arab Gulf.

Conferences: Annual three- or four-day international conferences or symposia are being held each summer, focusing on a chosen aspect of Arab Gulf affairs. The 1981 Symposium will be entitled: "Iraq: The Contemporary State."

$$
\begin{gathered}
\text {...Dr. M.A. Shaban, Director, U of Exeter, Exeter, Eng. } \\
\text { Islamic Texts Society }
\end{gathered}
$$

The Islamic Texts Society, a private non-profit association, was formed to provide accurate information on Islam and to make more of its literature available in English translation. The Society is also involved in producing audio-visual materials and in training teachers. For more information, write: Islamic Texts Society, c/o Mrs. A. Gouverneur, Parsonage Farmhouse, Great Sampford, Essex CB10-2RR, England.

\title{
Journal of Arab Affairs
}

The Journal of Arab Affairs is a journal of informed commentary published twice a year by the Middle East Research Group, Inc. (MERG), a California corporation. The first issue is scheduled for publication in October 1981 .

The articles that will appear in the Journal will not represent any consensus of beliefs and they will not be identified with any one school of thought. The Journal will be hospitable to many divergent and unconventional analyses of Arab affairs. Many of our readers, including members of the Journal's editorial board, will flatly disagree with some opinions and views expressed in some articles. However, we are determined to provide a forum for the unconventional and the daring.

The editor invites contributions on all aspects of contemporary Arab affairs. Address articles to: Editor, Journal of Arab Affairs, 2611 No. Fresno St., Fresno, CA 93703, U.S.A.

\section{Muqamas: An Annual of Ideas and Information on Islamic Art}

Muqarnas, edited by Oleg Grabar, sponsored by the Aga Khan Program for Íslamic Architecture, and published by Yale University Press, is now soliciting articles for its first volume, which is expected to appear in the spring of 1982. Since the new journal's first two volumes will include articles on a variety of subjects and areas, scholars may also contribute to Volume 2 for publication in the year follow- 